\title{
Lepsämänjoki LTSER: pitkäaikaisen sosioekologisen maatalousekosysteemitutkimuksen verkosto
}

Juha Helenius $^{1)}$, Irina Herzon ${ }^{1)}$, Reija Hietala ${ }^{1)}$, Maohua $\mathrm{Ma}^{1)}$, Sanna Tarmi ${ }^{1)}$, Jyrki Aakkula ${ }^{2)}$, Terho Hyvönen $^{2)}$, Reimund Rötter ${ }^{2)}$, Katriina Soini ${ }^{2)}$, Kirsti Granlund ${ }^{3)}$, Janne Heliölä ${ }^{3)}$, Mikko Kuussaari ${ }^{3)}$, Bertel Vehviläinen ${ }^{3)}$, Irmeli Ahtela ${ }^{4)}$, Leena Villa ${ }^{4)}$, Kirsti Lahti ${ }^{5)}$, Pasi Valkama ${ }^{5)}$, Laura Seppänen ${ }^{6}$, Juha Tiainen ${ }^{7}$, Anu Väinölä ${ }^{8)}$

${ }^{1)}$ Soveltavan biologian laitos, PL 27,00014 Helsingin yliopisto, etunimi.sukunimi@helsinki.fi

${ }^{2)}$ MTT Maa- ja elintarviketalouden tutkimuskeskus, 31600 Jokioinen, etunimi.sukunimi@mtt.fi

${ }^{3)}$ SYKE Suomen ympäristökeskus, PL 140,00251 Helsinki, etunimi.sukunimi@ymparisto.fi

${ }^{4)}$ UUS Uudenmaan ympäristökeskus, PL36,00521 Helsinki, etunimi.sukunimi@ymparisto.fi

${ }^{5)}$ VHVSY Vantaanjoen ja Helsingin seudun vesiensuojeluyhdistys ry, Asemapäällikönkatu 12 C, 00520

Helsinki,etunimi.sukunimi@vesiensuojelu.fi

${ }^{6}$ TTL Työterveyslaitos, Topeliuksenkatu 4la A,00250 Helsinki, laura.seppanen@ttl.fi

${ }^{7)}$ RKTL Riista- ja kalatalouden tutkimuskeskus, Viikinkaari 4, PL2, 00791 Helsinki. juha.tiainen@rktl.fi

${ }^{8)}$ Koulutus- ja kehittämiskeskus Palmenia, PL 58,00014 Helsingin yliopisto, anu.vainola@helsinki.fi

\section{Tiivistelmä}

Lepsämänjoki LTSER (long term social ecological research platform) kuuluu kahdeksan muun erilaisia ekosysteemityyppejä edustavan verkoston kanssa vuonna 2007 perustettuun Suomen LTSER -konsortioon (Fin-LTSER: http://www.ymparisto.fi/default.asp?contentid=257172\&lan=FI). Fin-LTSER puolestaan on samana vuonna hyväksytty kv. ILTER-verkostoon jäseneksi (http://www.ilternet.edu/). LTSER toiminnan perusajatus on luoda ja ylläpitää ekosysteemitutkimuksen infrastruktuureja, joissa pitkäaikainen ja seurantaaineistoihin perustuva tutkimus kohdistuu ns. ydinalueelle. Tällainen ydinalue on maantieteellisesti määritelty ekosysteemialue, jossa verkoston tutkimusryhmät tuottavat pitkäaikaista, julkista ja hyvin dokumentoitua seuranta- ja tutkimustietoa sosio-ekologisista ekosysteemin tilaan ja muutokseen sekä muutosta ohjaaviin voimiin liittyvistä muuttujista. LTSER verkoston tulisi mahdollistaa monitieteinen ja tieteidenvälinen sosioekologinen tutkimus, ja sen tulisi tuottaa laadukasta tutkimusdataa kv. tutkimusyhteisön käyttöön.

Lepsämänjoki LTSER on keskeisten maatalousekosysteemien tilasta ja muutoksesta kiinnostuneiden tutkimuslaitosten ja -ryhmien verkosto. Se on avoin yhteenliittymä, joka pyrkii kehittämään julkista ja yleishyödyllistä yhteistyötä ja infrastruktuuria maatalousympäristön monitieteiseen tutkimukseen. Verkoston ydinalue on Lepsämänjoen maataloudellinen valuma-alue, joka suurimmaksi osaksi kuuluu Uusimaalaisen Nurmijärven kunnan alueeseen noin $30 \mathrm{~km}$ Helsingistä luoteeseen $\left(60^{\circ} 23^{\prime}-60^{\circ} 28^{\prime} \mathrm{N}, 24^{\circ} 31^{\prime}-24^{\circ} 43^{\prime} \mathrm{E}\right)$. Se on topografialtaan laakea $213 \mathrm{~km}^{2}$ suuruinen alue, jossa harjoitetaan Etelä-Suomen savikoille ominaista peltoviljelyvaltaista maataloutta. Alueen pohjoisosassa on useita vihannesviljelyyn keskittyneitä tiloja. Alue on kaupungin läheistä maaseutua, jolle muualla työskentelevien haja-asutus leviää, ja jonka eteläosassa sijaitseva Klaukkalan taajama on kasvussa.

Lepsämänjoen valuma-alueelta on parhaimmillaan jo vuosikymmenten ajalta biofysikaalisiin ympäristömuuttujiin liittyviä tutkimusaineistoja: jokiveden laatu, maatalouden ravinne- ja kiintoaineskuormitus, maataloudellinen maankäyttö, maatalouden ravinnetaseet, maalajit ja topografia, alueekologinen monimuotoisuus, putkilokasvien, perhosten ja peltolintujen lajimonimuotoisuus. Verkoston eri tutkimusryhmät ovat toisistaan riippumatta koonneet em. aineistoja eri seurannoissa ja tutkimus- ja kehityshankkeissa.

Lepsämänjoki LTSER-verkoston tavoite on LTSER-konseptin mukaisesti verkostoitumisen avulla kehittää tutkimuksen infrastruktuuria, parantaa seuranta-aineistojen saatavuutta ja laatua sekä edistää ekologisen, ympäristö- ja yhteiskunnallisen tutkimuksen integraatiota. Tiedustelut voi osoittaa verkoston koordinaattorille (juha.helenius@helsinki.fi).

Asiasanat: Fin-LTSER, ILTER, ekosysteemitutkimus, DPSIR, EAM, metadata 


\section{Tausta}

Julkisesti rahoitetuissa seurannoissa ja tutkimushankkeissa kootaan runsaasti ekologisen ja ympäristötutkimuksen aineistoja. Yhä useammin hankkeet ovat myös monitieteisiä, jolloin esim. yhteiskunnalliset ja biofysikaaliset osa-aineistot kootaan samassa hankkeessa. Usein hyvinkin suuren rahoituksen vaatineen, runsaasti tutkijatyötä edellyttäneen ja mahdollisesti tutkimuslaitteistoja pystyttäneen hankkeen perusaineistot jäävät hankkeen päätyttyä ja omien julkaisujen laadinnan jälkeen vaille käyttöä. Usein aineistot jäävät vaille selkeää dokumentointia, ns. metadataa. Aineistot suorastaan rapautuvat, hautautuvat mappeihin, rappeutuvat digitaalisissa tallenteissaan, ja vähitellen unohtuvat tutkimushenkilöstön luonnollisesti vaihtuessa. Jopa ainutlaatuisen tärkeät pitkäaikaisen seurannan aineistot ovat olleet yksittäisen laitoksen vastuulla, tai jopa yksittäisen tutkijan elämänuran omistautumisen varassa.

Näihin haasteisiin on tarttunut kansainvälinen pitkäaikaisen ekosysteemitutkimuksen verkosto ILTER (Long Term Ecological Research, perustettu 1993). Sen tavoitteena on edistää ekosysteemitutkijoiden yhteistyötä paikallisesti, alueellisesti ja globaalisti, parantaa eri puolilla maailmaa koottavien pitkäaikaisaineistojen vertailukelpoisuutta sekä dokumentointia, säilyttämistä ja saatavuutta, tuottaa tieteellistä tietoa tutkimusyhteisölle, politiikan tekijöille ja suurelle yleisölle, kehittää parhaita ekosysteemilähestymistapaa (EAM, ecosystems approach to management) noudattavia käytäntöjä hoidon ja hallinnoinnin eri tasoille, sekä edistää tutkijakoulutusta pitkäaikaistutkimukseen (http://www.ilternet.edu/).

Aluksi LTER toiminta keskittyi ekologisiin ja biofysikaalisiin tutkimuksiin, mutta nopeasti kävi ilmeiseksi, että yhteiskunnallinen relevanssi edellyttää integroitua yhteiskuntatieteellistä sekä ekologista tutkimusotetta. Näin syntyi käsite pitkäaikaisesta sosio-ekologisesta tutkimuksesta, joka toi LTER lyhenteeseen tuon s-kirjaimen: LTSER. Usein käytetty käsitteellinen väline LTSER tutkimuksessa on ns. DPSIR-ketju (drivers - pressures - states - impacts - responses), ajatus ympäristömuutoksen, sen estämisen toimenpiteiden sekä siihen sopeutumisen aiheuttajista, paineista, tilasta, vaikutuksista ja vasteista.

Suomen pitkäaikaisen ympäristötutkimuksen verkosto Fin-LTSER perustettiin 2007, ja hyväksyttiin samana vuonna ILTERin jäseneksi. Fin-LTSER määrittelee ympäristötutkimuksen monitieteiseksi, ja edustaa näin olleen sosio-ekologista tutkimusotetta. Verkostoon hyväksyttiin kansallisen haun ja ulkopuolisen vertaisarvioinnin jälkeen yhdeksän LTER- tai LTSER -aluetta (http://www.ymparisto.fi/default.asp?contentid=257172\&lan=FI) . Nämä ovat useiden toimijoiden, sekä tieteellisten että muiden intressiryhmien yhteenliittymiä, maantieteellisesti vaihtelevasti rajautuvia, ja erilaisia ekosysteemityyppejä kattavia. Kaikki perustamiskierroksella vaatimukset täyttäneet alueet eivät kuitenkaan hakeneet tai saaneet LTSER-statusta. LTSER-status edellyttää riittäviä edellytyksiä sosio-ekologiseen tutkimukseen.

Maatalouden tutkimuskysymyksiä käsitteleviä Fin-LTSER -verkoston alueita ovat Lammi LTER (Southern Boreal Aquatic and Terrestrial Long Term Ecological Research Area), Western Gulf of Finland LTERsite WelFin, Bothnian Bay LTSER-platform, sekä ainoana nimenomaan maatalousekosysteemien kysymyksiin keskittyvänä Lepsämänjoen pitkäaikaisen sosioekologisen maatalousekosysteemitutkimuksen verkosto (LAWA Lepsämänjoki agricultural watershed area LTSER). (http://www.ymparisto.fi/download.asp?contentid=66827\&lan=fi)

\section{Lepsämänjoki LTSER}

Lepsämänjoki LTSER syntyi osallistuvien tutkimusryhmien huomatessa työskentelevänsä yhteiskunnallisesti rakentuneiden ympäristökysymysten parissa samalla pienehköllä Uusmaalaisella valuma-alueella. Yhteistyön ydinalue on maataloudellinen $213 \mathrm{~km}^{2}$ valuma-alue, joka suurimmaksi osaksi kuuluu Nurmijärven kunnan alueeseen noin $30 \mathrm{~km}$ Helsingistä luoteeseen $\left(60^{\circ} 23^{\prime}-60^{\circ} 28^{\prime} \mathrm{N}, 24^{\circ} 31^{\prime}-24^{\circ} 43^{\prime} \mathrm{E}\right)$. Alue edustaa eteläboreaalista maataloutta, joskin sen erityispiirteenä on vihannesviljelyn keskittymä alueen pohjoisosassa. Alue on kaupungin läheistä maaseutua, jolle muualla työskentelevien haja-asutus leviää, ja jonka eteläosassa sijaitseva Klaukkalan taajama on kasvussa.

Lepsämänjoen valuma-alueelta on parhaimmillaan jo vuosikymmenten ajalta biofysikaalisiin ympäristömuuttujiin liittyviä tutkimusaineistoja: jokiveden laatu, maatalouden ravinne- ja kiintoaineskuormitus, maataloudellinen maankäyttö, maatalouden ravinnetaseet, maalajit ja topografia, alueekologinen monimuotoisuus, putkilokasvien, perhosten ja peltolintujen lajimonimuotoisuus. Verkoston eri 
tutkimusryhmät ovat toisistaan riippumatta koonneet em. aineistoja eri seurannoissa ja tutkimus- ja kehityshankkeissa.

Perustamisvaiheessa Lepsämänjoki LTSER -alueen tutkimusyhteisöön kuuluvat Helsingin yliopiston, MTT Maa- ja elintarviketalouden tutkimuskeskuksen, SYKE Suomen ympäristökeskuksen, UUS Uudenmaan ympäristökeskuksen, VHVSY Vantaanjoen ja Helsingin seudun vesiensuojeluyhdistyksen, TTL Työterveyslaitoksen sekä RKTL Riista- ja kalatalouden tutkimuskeskuksen tutkimusryhmät.

Perustamisvaiheessa Lepsämänjoki LTSER määritteli tavoitteikseen:

- yhdistää (alueella tapahtuva) agroekosysteemin rakenteen (maankäytön) ja toiminnan (prosessien) muutos sosioekonomisiin ja poliittisiin aiheuttaviin tekijöihin (drivers)

- edistää (alueella toimivien tai temaattisesti vastaavien) tutkimus- ja seurantahankkeiden yhteistyötä

- tutkia, seurata ja analysoida:

○ biologisen monimuotoisuuden muutosta ekosysteemi- ja lajitasolla, sekä tuotannollista että luonnonvaraista monimuotoisuutta koskien

○ hydrologiaa ja vedenlaatua, erityisesti ravinne- ja maa-aineskuormitusta mm. automatisoidun vedenlaadun seurannan avulla

○ maatalouden tuotantotapojen ja panoskäytön muutosta

○ maakäytön, maatalouden, maanomistuksen ja väestön sosioekonomista muutosta, mukaan lukien maaseudun ja kaupungin rajalla tapahtuva muutos

- edistää alueen toimijoiden, tutkimuksen asiakkaiden ja osakkaiden oppimista ympäristön suojeluun sekä ekosysteemipalvelujen kestävään käyttöön liittyen

\section{Maatalousekosysteemeihin kohdistuva LTSER toiminta jatkossa}

LTSER-toiminnan lähtökohta on pitkän aikavälin lähestymistapa. Monet keskeisistä ekologisista prosesseista ja ongelmista, kuten esimerkiksi ilmaston muutos ja biodiversiteetin väheneminen, tapahtuvat pitkällä aikavälillä ja vähittäin. Lyhytkestoiset tutkimushankkeet tarvitsevat rinnalleen tutkimusta, joka tuottaa aineistoa globaalimuutoksen ja politiikkamuutosten vaikutuksista ympäristöön. Tällainen seurantaaineistoihin perustuva tutkimus vaatii pysyviä infrastruktuureja, toki pysyviä vain kilpailutuksen ja säännöllisen vertaisarvioinnin ehdoin. Olennainen osa LTSER -tutkimusta on tutkimusaineistojen korkealaatuinen dokumentaatio, ns. meta-data, jonka samoin kuin julkisin varoin tuotettujen perusaineistojen tulee olla saatavilla verkosta vapaasti ja kansainvälisesti tutkimusryhmien käyttöön.

Fin-LTSER osallistuu kansalliseen ja kansainväliseen (EUn ESFRI, jossa LIFE-WATCH) infrastruktuuriprosessiin, tavoitteenaan mahdollistaa riittävä ja riittävän pitkäaikainen infrastruktuuri Suomen LTSER tutkimukselle. Toistaiseksi suomalaiset LTER ja LTSER alueet, Lepsämänjoen LTSER mukaan lukien toimivat ilman kohdennettua ulkopuolista rahoitusta jäsenlaitostensa käynnissä olevien tutkimus- ja seurantahankkeiden sekä niihin osoitetun henkilötyöpanoksen varassa. Verkostoitumista on kuitenkin jo voitu LTSER tavoitteiden suunnassa hyödyntää tutkimusohjelmahakuihin valmistauduttaessa. Suomen LTSER toiminta on juuri käynnistynyt vuonna 2007, ja osallistuvien laitosten, tutkijoiden ja tutkimusryhmien kiinnostuksesta ja sitoutuneisuudesta sekä julkisten rahoittajien priorisoinneista riippuu, missä määrin sitä voidaan hyödyntää monitieteisen ja tieteidenvälisen, yhteiskunnallisesti relevantin ympäristötutkimuksen tekemisessä.

\section{Lisätietoja:}

\section{ILTER: http://www.ilternet.edu/}

\section{Fin-LTSER:}

- Koordinaattori professori Martin Forsius, Suomen ympäristökeskus

- $\quad$ http://www.ymparisto.fi/default.asp?contentid=257172\&lan=FI

- esite: http://www.ymparisto.fi/download.asp?contentid=66827\&lan=fi

Lepsämänjoen maatalousekosysteemin LTSER:

- Koordinaattori professori Juha Helenius, Helsingin yliopisto 